\title{
SUSTAINED YIELD FROM CANADIAN FORESTS FOR THE SUPPORT OF PERMANENT FOREST INDUSTRIES.

\author{
PROVINCIAL RESPONSIBILITY AND PROGRAM
}

\author{
By E. C. ManNing
} Chief Forester for British Columbia and Assistant Timber Controller for
British Columbia

TF THERE BE any truth in the saying that we often can't see the forests for the trees thereof, I hope I shall have gained an improved perspective for having been submerged during the last six months in a war'production effort not even remotely associated with the subject of sustained yield. Never. theless, I approach this subject of "The Responsibility and Program of a Provincial Service in the Introduction of 'Sustained Yield from Canadian Forests" with a feeling of apprehension over my ability to do it justice.

May I state at the commencement that I shall attempt to make my remarks applicable to Canada in general, and that I do not refer to British Columbia especially unless I so designate. During my trips to the East in the last few years I have contacted foresters from all the Provinces, and certain definite impressions from my discussions with them remain with me. The opinions I offer are simply those of a member of this Society, who believes that, unless we possess the right of dissociating ourselves from our official positions and discussing our problems frankly in the interests of forestry, we might as well stay home and save ourselves the time and expense of attending these meetings.

What is the first essential in the introduction of sustained yield? In a democracy it is the education of the public to the need of it. Why? Because in no other way will a permanent progressive policy be ensured. By whom should the public be informed? By those who know. The informing of the public and its governmental representatives is, therefore, the duty of that class of trained men best qualified, the foresters, and, ipso facto, it becomes the first great responsibility of a Provincial Forest Service. The staff has the knowledge and they have no other than the public interest to serveor should not have. Any service to which this statement does not apply is badly in need of an immediate overhaul of personnel.

I state with regret that in Canada reports on forest resources and forestry measures needed appear to be too often edited, not with the sole idea of accuracy and completeness of statement, but having in mind the reaction of the business and political interests affected. The forester who forgets to tread softly in any public presentation will undoubtedly be reminded of his omission. The logic of the situation is simple. Any presentation on the forestry situation showing that conditions are unsatisfactory and that certain remedies are needed is apt to be interpreted by political opponents to the disadvantage of the government of the day. Where remedies that cost money are involved, finance ministers do not look kindly on such expenditures largely in the interests of a generation not yet represented at the polls. Influential business interests watch any policy that may affect their profits. 
The final result is that forestry facts and remedies are largely interpreted to the public by or under the direction of elected representatives of the people. Undoubtedly it is not the function of a member of a Provincial Forest Service to criticize, dictate, or announce government policy, but as clear an obligation as loyalty itself to the government is the duty to report and recommend very frankly to the government, and in no way associate oneself with any partial truth which may be issued for public consumption. The forester should always be on the aggressive alert to urge that which is in the public interest. The senior foresters of Canada to date have not distinguished themselves in the performance of this duty. There are others, not foresters, in authority in Canada today, who appear to be actually retarding progress. So we keep very quiet or stick to strictly technical discussions and emphasize planting and protection matters, partly because they are no longer controversial and appeal to the public fancy. Planting in itself may be an excellent measure, but care must be taken lest we delude ourselves into thinking a big planting program takes the places of a real forest policy.

Progressive forestry policies involved in the "introduction of sustained yield" will not exist in this democracy of Canada until facts and remedies are established and made public property and until the need of forest policies is explained, advocated and popularized. This is the first responsibility of a Forest Service which, I repeat, should be the most competent authority to perform the work.

In the Province of British Columbia the main facts concerning our forest resources have been established and published. The government, every member of the legislature, every important paper in the Province, and hundreds of our citizens have been supplied for the last four years with an accurate review of our forestry situation as presented to the Forestry Committee of the legislature. It is to the credit of the government that they admitted the situation in their report to the Rowell Commission, which in return confirmed same in their submission to the Dominion Government.

We are making progress. There still remains much to be done here, particularly in educating the public and popularizing forest policy. Lack of finances will be our main deterrent to progress in the future.

Having dealt with the primary responsibility of a Provincial Service, let us enumerate certain important policies which must be followed in carrying out the resultant program.

1. Of late we have heard considerable of the multiple use of forest areas, in which recreational use is being stressed. It has taken us a long time to recognize the economic soundness of multiple use and the value of it as a selling feature for our forest policy. Dr. Filbert Roth, the Doyen of Forestry in the Lake States, in a lecture in February, 1907, stated, "I consider that forest functions, and benefits in their totality, are many times as valuable and important as is the immediate log yield." Dr. B. E. Fernow in effect said the same thing in an address in Montreal in 1908 to the Canadian Forestry Association. The British Columbia Forest Service has been stressing multiple use for some years. It initiated development of the provincial parks, finally secured control of them last year, and wrote a new chapter of the "Forest Act" to cover them. There are now three classes of provincial parks: 
(a) Those where recreational interests are paramount and other uses must be subordinated to them.

(b) Those where recreational uses go hand in hand with others, such as farming and logging.

(c) Those of a strictly community nature, mostly small, the administration of which is placed in the hands of local park boards, and for which the Service does not want responsibility.

The Service is associating itself actively with the skiing interests. Gentlemen, don't overlook any opportunity in this respect. Skiing is the coming national sport of Canada.

The Service is cooperating very closely with the Game Department to the mutual advantage of both. It is identifying itself actively with the Fish and Game interests.

The work of the British Columbia Forest Service in the Young Men's Forest Training Camps is too well known to need any elaboration.

2. Land classification is a basic need of forestry, agriculture and roadbuilding program. For fifteen years the Forest Service has advocated it in British Columbia. Only in the field of forestry does land classification seem to have received the recognition and support to which it is entitled.

3. I believe in a concentration of forestry effort on the most accessible and most productive of our forest areas. This is particularly difficult in forest protection work. The dedication of large areas to timber growing, as has been done in British Columbia, is commendable, but not until we have more actively promoted the objective of sustained yield within those units does the policy become really effective.

4. The practice of forestry by private owners should be encouraged. We should advocate such measures as reduced taxation and free planting stock to promote it. Unfortunately, the supposed inexhaustibility of our forest wealth to date has been a deterrent, and so far as this Province is concerned, I do not feel very hopeful of progress in the immediate future, except in the case of small landholders and one or two big pulp and paper companies.

5. This brings us to the subject of public regulation of private areas. Undoubtedly the public has the right to expect a private owner to keep his land in a productive condition, especially where the public interest is so vitally concerned as in our large forest areas here on the coast. However, the public should bear a portion of the cost, and failure to supply the funds will seriously retard the whole program, even if the necessary legislation requiring the operator to perform his responsibility be in effect. In the United States the sentiment in favour of public regulation of private cutting is definitely strengthening. Canadians may expect certain opposition from business interests in this connection.

6. Sustained yield must rest upon sound economic foundations in which costs are returned in some form or other. For years I have watched with uneasiness the depletion of this Province's greatest natural resource, in which there was little balance between amount of accessible standing timber, production, selling price and market demand. Competition within the industry was an influential factor, and the cost of the replacement of the crop a negligible consideration. 
For the first time in the history of Canada, the great timber industry has come under a government control that can completely override private rights. I like to think that the same spirit of co-operation which I have seen exhibited by the industry in British Columbia, in the prosecution of the war effort, may make possible an orderly production and marketing of our forest products in peace time which will ensure adequate returns, avoidance of waste, and will protect the rights of the next generation.

7. This discussion is not complete without reference to the respective responsibilities of the Provincial and Dominion Forest Services. The subject cannot be disposed of effectively by stating that certain phases of forestry should be handled exclusively by the Dominion and certain phases by the Provincial Services.

Conditions vary in different parts of Canada, both in respect to the problems involved and the ability of the local Provincial Services to perform certain functions. There should be no overlapping, but rather a co-ordination of effort.

So far as British Columbia is concerned, I believe the Dominion Forest Service should have exclusive occupancy of the field of research in forest products and the Provincial Service the field covered by our Economics Division, particularly in respect to silviculture. There might, however, be some argument for the Dominion engaging in silvicultural work in our spruce forests, as a type of work which stretches across Canada. There is an argument for their participation in forest protection research in the various Provinces, and particularly I believe that some assistance by the Dominion to the Provinces, similar to the Clarke-McNary Act of the United States, should be forthcoming.

I would like to emphasize the necessity of the Dominion giving the Provinces some concrete assistance in forest protection. Planting, silvicultural practice and regulation of industry, all expensive expedients designed to keep forest lands productive, are largely wasted unless we provide adequate protection. In Canada protection must be the cornerstone of any sustained yield program, to the cost of which the Dominion should be contributing. The Provinces generally are already spending as much on protection as their finances will permit. The Dominion, drawing great revenue from forest resources, might well help, if for no other reason than to protect and insure that revenue.

Undoubtedly, great opportunity exists for forestry leadership at Ottawa, clear-visioned and courageous. To that we can all agree and wish the Dominion Forest Service in its respective fields the greatest of progress.

In conclusion, may I admit that this paper will disappoint some because of its scant reference to the subjects of sustained yield, rotations, increments, and like technical factors. Such will only really come after we have made an honest valuation of the situation, after the public has been accurately informed by those competent to interpret the many misleading factors involved, and after the public interest becomes the first consideration of all. 